\author{
Ali Turan Bayram \\ https://orcid.org/0000-0003-1655-4043 \\ Sinop University \\ School of Tourism and Hospitality Management \\ Department of Tour Guiding \\ alibayram@sinop.edu.tr \\ Hasan Tahsin Kavlak \\ https://orcid.org/0000-0003-0036-9652 \\ Sinop University \\ School of Tourism and Hospitality Management \\ Department of Recreation \\ htkavlak@sinop.edu.tr \\ Jeet Dogra \\ https://orcid.org/0000-0002-8786-2134 \\ Indian Institute of Tourism \& Travel Management (IITTM) \\ (Autonomous Body under Ministry of Tourism, Govt. of India) \\ jeetdogra@live.com \\ Gül Erkol Bayram \\ https://orcid.org/0000-0001-9764-2883 \\ Sinop University \\ School of Tourism and Hospitality Management \\ Department of Tour Guiding \\ gulerkol@sinop.edu.tr
}

\title{
HOPELESSNESS AGAINST DESIRE TO PURSUE A CAREER IN TOURISM: AN EMPIRICAL ANALYSIS OF SINOP UNIVERSITY, TURKEY
}

\begin{abstract}
The aim of this work is to demonstrate the relationship between the level of hopelessness of students in tourism education and their desire to make a career in tourism. The data was collected from bachelor-level students in Sinop, a city at the top of Turkey's life satisfaction and happiness index, by using a survey technique. In order to describe the data collected, frequency and arithmetic mean tests were used, whereas t-tests and variance analysis were used to determine differences between variables, and correlation was used to determine the relationship. As a result of the research, it was found that there is a negative relationship between the desire to make a career in tourism and level of hopelessness amongst the students.
\end{abstract}

Keywords: tourism education, careers of tourism students, careers in tourism, level of hopelessness and desire, tourism students.

\section{INTRODUCTION}

Individuals in society see a professional career as a tool to meet needs such as gaining social status, creating a social identity, and self-realization. In an economic system, a career can be considered as a factor that affects the commitment of employees to an organization, a reduction in managerial problems and an increase in organizational productivity. Therefore, the relationship between career and internship (Gault, Redington, Schlager, 2000), family business experience and career choice (Zellweger, Sieger, Halter, 2011), personal preferences and career expectations (Jarlström, 2000), career choice and gender identity (Eddleston, Powell, 2008), foreign education and career goals (Orahood, Kruze, Pearson, 2004), job failure and career choice (Simmons, Wiklund, Levie, 2014) have been subjects of important academic studies. In addition to these, it is thought that one of the factors that can affect 
a career is hopelessness. Its effect in the tourism sector is especially a matter of curiosity because this sector is seen as one with low career opportunities due to its flexible and fragile structure, a seasonal perception by both employees and consumers, and labor-intensive, so even students who receive an education in tourism are less likely than average to pursue a career (Akagündüz, 2017).

It is stated that a career is an outcome of social roles not only in working life but throughout life (Amil, 2015; Yeşilyaprak, 2012). From this point of view, interacting environments such as social, technological and economic can also affect an individual's despair. When geographical location, economic status and the intensity of social relationships are considered, Turkey is as a place where young people have a high level of despair. There is some research related with this, for example Yildırım and Toker (2017) found a negative relationship between hope and future expectations.

In addition to these statements, the relationship between hopelessness and career tendencies should be examined from different perspectives. Revealing this relationship among tourism students is seen as important for the development of the tourism sector. As a matter of fact, the standard of service provided for tourist satisfaction is important, as tourists establish close relationships with tourism staff during consumption (Heskett, Jones, Loveman, Sasser Jr, Schlesinger, 1994) because it is difficult to ensure customer satisfaction without the positive attitude of employees towards their jobs and the company (Rosentbluth, 1991). In the context of the relevant literature, there is very little work on this relationship. With such studies, the development of tourism theories, the integration of theoretical foundations within different disciplines and the positive development of the sector could be achieved. Based on this information, this work aims to reveal the relationship between the level of hopelessness of students who receive tourism education and their desire to pursue a career in tourism. The results of the research are expected to contribute to the issues faced by qualified staff and also to the tourism literature in Turkey.

\section{LITERATURE REVIEW}

A career means "stages to be overcome in a profession, the chosen direction in life" (Aydın, 2007), and the stage, success and expertise achieved in a profession through time and work (Türk Dil Kurumu Sözlükleri, 2020). However, as with most social sciences, there are different perspectives on the concept of career. Raymond (2009) states that a career is seen by some authors as the promotion and professional progress that a person has achieved throughout his/ her working life, and that others authors see it as progress in the profession itself. On the other hand, it is stated that a career is an output of roles that continues throughout the life of the individual, not merely working life (Amil, 2015; Yeşilyaprak, 2012). A career can provide benefits such as gaining social status for employees, creating identity, meeting the need for self-realization, and can be a positive factor for organizations to increase efficiency and loyalty and decrease administrative problems. For this reason, the creation of a career and the desire of employees to make one should be among the subjects on which the academic community places importance both in terms of practice and theoretically.

A career, which is the subject of many studies (Akagündüz, 2017; Bamford, 2012; Selvi, Demir, 2007; Solmaz, Erdoğan, Türkay, Korkutata, 2012; Watson, Drew, 2015) has an important place in the tourism sector in spite of the expectations and satisfaction levels of tourism students (Manhas, Dogra, 2011). Proof of this situation is found in a work where the perceptions of tourism students towards the industry were investigated (Bamford, 2012) and their perceptions towards the tourism sector and the desire to pursue a career in it were found to be negative due to reasons such as low wages, long working hours, low respect between employees and the need for education. It is stated that $73 \%$ of the graduates work in the tourism sector but, due to the high turnover of personnel not only during the university period but also after graduation, only $21 \%$ of them complete their career plans and work in managerial positions ( $\mathrm{O}^{\prime}$ Leary, Deegan, 2005). While most of the students studying tourism are eager to choose the tourism sector, they do not want to work there after graduation due to 'lack of spiritual satisfaction' and working conditions (such as dissatisfaction with social conditions, insufficient wages). In fact, whenever possible, they want to end their education in tourism and study something else (Pektaş, 2019).

One of the factors affecting the desire to make a career in the tourism sector is the internship carried out during the tourism education process. Even participants who appear to be committed to a career in tourism are not sure if they want their careers to develop after this (Walmsley, Thomas, Jameson, 2012). Roney and Öztin (2007) supported this statement by revealing that students who study tourism are reluctant to work in the industry after graduation after having experience working in it. Although the perception within the community is that the careers of individuals who are diligent in their educational lives are more positive; planning and working has only a 9.3\% explanatory power over tourism career intentions. Therefore, it is stated that not only work but also 'professional care' affects career development because diligence is not the only factor in a career (Baltacı, Çakıcı, Dönmez, 2019). 
Yildirim and Toker (2017) found no meaningful relationship between the level of despair and the career choice of students studying tourism at an undergraduate level, but found a negative relationship between hope and expectations about the future. Rottinghaus, Jenkins, and Jantzer (2009) found that students who did not make a career decision were in more depressed moods than those who had taken one. It is also stated that there is a positive relationship between the level of hopelessnes and the negative attitudes of students towards the tourism sector (Çelik, Akgemci, Korkmaz, 2017). It has been suggested that the education levels of workers in the tourism sector are lower than in others (Purcell and Quinn, 1996) and that it is seen as a lowstatus profession and therefore perceived as a low-career value (Cooper, Shepherd, 1997). In addition to these reasons, it has been stated that individuals who have studied tourism have left due to sectoral conditions, having no motivation to pursue a career in tourism further (Koko, Guerrier, 1994).

The desire to pursue a career in the tourism sector shows fragility and flexibility just like the structure of tourism itself. Bamford (2012) revealed that students' perceptions of the tourism sector and the desire to pursue a career in it are negative due to reasons such as low wages, long working hours, low respect among employees, and the ability to do things without training. It has been revealed that students who have received tourism education are reluctant to work in the sector after experience working in it after graduation (Roney, Öztin, 2007). From the perception of tourism students, the industry has the poor image of either lacking or having few qualified staff who work for longer periods of time (Jenkins, 2001). In addition to these factors, demotivating ones such as low job satisfaction, waste of qualified personnel, a high personnel turnover rate also lead to a decrease in the desire to enter the sector as an employee (Jenkins, 2001; Pavesic, Brymer, 1990).

All these statements show that a desire to make a career in tourism is related to many factors. One of these and perhaps the one that bridges social life and career is hope/despair. As a matter of fact, students often experience psychological problems while making a career decision (Fouad et al., 2006). As proof of this, Rottinghaus, Jenkins, and Jantzer (2009) found that students who did not make a career decision were more depressed compared to students who had taken one. It is also stated that there is a positive relationship between the level of hopelessness of students and their negative attitudes towards the tourism sector (Çelik, Akgemci, Korkmaz, 2017). It has been suggested that the education level of those working in it is lower than in other sectors (Purcell and Quinn, 1996), and it is perceived as a low-status profession and therefore one with a low career value (Cooper, Shepherd, 1997)
In addition to these reasons, it is also stated that individuals who have received tourism education leave due to sectoral conditions, feeling unmotivated and without hope about making a career in tourism (Koko, Guerrier, 1994). Therefore, it can be said that the variables of 'making a career in tourism' and 'hopelessness' are effective on students who receive tourism education. In this context, this research is based on Beck's cognitive depression model where Beck (1987) states that individuals' behavior is shaped by three factors: "individuals" negative views towards themselves, towards the world and towards the future." Individuals who see themselves inadequate and flawed are individuals who criticize and feel worthless. Those who negatively evaluate the world are the ones who cannot cope with the obstacles they face throughout their lives. He further stated that individuals who look negatively towards the future are those who think that the obstacles they face will continue and there is no hope. Career desire and action for the future due to university education, is the third factor in Beck's Cognitive Depression Model based on negative thinking.

All these suggest that factors that may be related to the desire of tourism students to pursue a career should be studied in different sample groups and at different times. Moving on, in this study from Turkey, the happiest and highest quality of life as found in the city of Sinop, is contrasted with the tourism education of students and their level of hopelessness, and is intended to reveal the relationship between this and a career. It is thought that the results obtained from the research will contribute to the literature, the educational processes of the institutions providing tourism education and the management of tourism enterprises.

\section{METHOD}

According to the Turkish Statistical Institute (TUIK, 2020), the tourism sector has the least confidence among the all sectors in Turkey with a rate of just $55.5 \%$. On the other hand, acccording to Acer (2019) and TUIK (2019), Sinop has the highest level of life satisfaction and happiness in Turkey. Based on this information, undergraduate students at Sinop University School of Tourism and Hotel Management constitute the population of this research. Its aim is to reveal the relationship between the level of hopelessness of tourism students at undergraduate level and their desire to pursue a career in tourism sector. In 2019, there were 803 registered students studying in five different departments: Accommodation management, Tour guidance, Food and Beverage management, Recreation management, Gastronomy and Culinary arts (School of Tourism and Hotel Management, 2020). 
The data was collected through questionnaires from 395 students selected by a simple random sampling method between 1 st to 15 th October 2019. However, as incorrect and incomplete questionnaires were excluded from the analysis, only 380 were evaluated. The questionnaire consisted of three parts. In the first there were 11 statements asking for demographic characteristics (age, gender, etc.) and other information (reason for choosing the tourism department, your choice of tourism department, etc.). In the second part, there was a "Desire to Make a Career in Tourism Scale" consisting of 10 statements and a single dimension regarding students' desire to pursue a career in tourism: a 5-point Likert type $(1=$ never agree, $2=$ less agree, $3=$ moderately agree, $4=$ highly agree, $5=$ totally agree). The 'Scale of Willingness to Make Careers in Tourism' was developed by Kusluvan and Kusluvan (2000) and it was adapted to Turkey by Duman, Tepeci and Unur (2006). In the third part, there are 20 statements developed from Beck, Weissman, Lester and Trexler (1974).

\section{RESULTS}

The data obtained from the questionnaires were analyzed using SPSS 22 to reveal the relationship between levels of despair of university tourism students and their desire to pursue a career in the tourism sector. In the first stage, demographic characteristics and other information on the students were described with frequency analysis and an arithmetic mean. In the second stage, t-test and variance analysis were used on two independent samples to reveal the differences in level of despair, and desire to have a career in tourism according to demographic and other information. At the last stage, in order to reveal the relationship between students' level of despair and their desire to pursue a career in tourism, a correlation analysis was made to conclude the findings.

According to the data in Table 1, 50.5\% of the students participating in the research are female and $49.5 \%$ are male. $27.4 \%$ of these students are in "accommodation management", 24.5\% "food and beverage management", 32.9\% "tourist guidance", 7.1\% "recreation management" and 8\% in "Gastronomy and Culinary Arts". Concerning reasons for choosing departments, it was found that the highest rate with $37.4 \%$ was "according to my results" and the lowest was "relatives' advice" with $7.6 \%$. In addition, the rate of those who choose the department voluntarily is $68.7 \%$. While $46.1 \%$ of the students participating in the research see themselves as mid-level managers in five years, $74.5 \%$ see themselves as top-level managers in fifteen.

As given in Table 2, students have an average of 7.4395 , with a maximum score of 20 , while desire to pursue a career in tourism, with a maximum of 5 , has an average of 3.2303 .

On Table 3, there was no significant difference in the students' desire to pursue a career in tourism based on demographic characteristics such as gender. However, among other features, a significant difference was found according to information on "voluntarily choosing the tourism department" and "a relative who works in tourism". According to those who choose tourism voluntarily, those who have a relative working in the tourism sector are more willing to have a career in tourism than those who do not.

Table 1. Demographic profile and other information

\begin{tabular}{|c|c|c|c|}
\hline Demographic features and other information & Variable(s) & $\begin{array}{c}\mathrm{N} \\
(380)\end{array}$ & $\begin{array}{c}\% \\
(100)\end{array}$ \\
\hline \multirow{2}{*}{ Gender } & Female & 192 & 50.5 \\
\hline & Male & 188 & 49.5 \\
\hline \multirow{3}{*}{ Age } & $17-19$ & 118 & 31.1 \\
\hline & $20-22$ & 208 & 54.7 \\
\hline & 23 and Above & 54 & 14.2 \\
\hline \multirow{5}{*}{ Department } & Department of Hospitality Management & 104 & 27.4 \\
\hline & Food and Beverage Management & 93 & 24.5 \\
\hline & Tourism Guidance & 125 & 32.9 \\
\hline & Recreation Management & 27 & 7.1 \\
\hline & Gastronomy and Culinary Arts & 31 & 8.2 \\
\hline \multirow{4}{*}{ Class } & 1. class & 161 & 42.4 \\
\hline & 2. class & 156 & 41.1 \\
\hline & 3. class & 44 & 11.6 \\
\hline & 4. class & 19 & 5.0 \\
\hline
\end{tabular}


Table 1 (cont.)

\begin{tabular}{|c|c|c|c|}
\hline Demographic features and other information & Variable(s) & $\begin{array}{c}\mathrm{N} \\
(380) \\
\end{array}$ & $\begin{array}{c}\% \\
(100) \\
\end{array}$ \\
\hline \multirow{5}{*}{ Reason for choosing the department } & Based on my results & 142 & 37.4 \\
\hline & Loving this job & 116 & 30.5 \\
\hline & This job is valid for the tourism industry & 55 & 14.5 \\
\hline & I had no other choice & 38 & 10.0 \\
\hline & Relatives' advice & 29 & 7.6 \\
\hline \multirow{3}{*}{$\begin{array}{l}\text { In which order was the tourism department in your } \\
\text { university preferences? }\end{array}$} & $1-5$ & 222 & 58.4 \\
\hline & $6-10$ & 96 & 25.3 \\
\hline & 11 and above & 62 & 16.3 \\
\hline \multirow{2}{*}{ Did you prefer the tourism department voluntarily? } & Yes & 261 & 68.7 \\
\hline & No & 119 & 31.3 \\
\hline \multirow{2}{*}{$\begin{array}{l}\text { Do you have any relatives working in the tourism } \\
\text { sector? }\end{array}$} & Yes & 218 & 57.4 \\
\hline & No & 162 & 42.6 \\
\hline \multirow{4}{*}{$\begin{array}{l}\text { Where do you see yourself in the tourism sector within } \\
5 \text { years? }\end{array}$} & Senior Manager & 139 & 36.6 \\
\hline & Mid-level Manager & 175 & 46.1 \\
\hline & Sub-Tier Manager & 12 & 3.2 \\
\hline & Nowhere & 54 & 14.2 \\
\hline \multirow{4}{*}{$\begin{array}{l}\text { Where do you see yourself in the tourism sector within } \\
15 \text { years? }\end{array}$} & Senior Manager & 283 & 74.5 \\
\hline & Mid-level Manager & 40 & 10.5 \\
\hline & Sub-Tier Manager & 7 & 1.8 \\
\hline & Nowhere & 50 & 13.2 \\
\hline
\end{tabular}

Source: authors' elaboration.

Table 2. Arithmetic average and standard deviation according to students' levels of despair and the pursuit of a career in tourism

\begin{tabular}{|l|c|c|c|c|}
\hline \multicolumn{1}{|c|}{ Variable } & Arithmetic mean & Standard deviation & N & $\%$ \\
\hline Level of hopelessness & 7.4395 & 4.19121 & 380 & 100 \\
\hline Willingness to make careers in tourism & 3.2303 & 0.91441 & 380 & 100 \\
\hline
\end{tabular}

Source: authors' elaboration.

Table 3. T-test findings on differences in willingness to pursue a career in tourism according to demographic and other information

\begin{tabular}{|l|c|c|c|c|}
\hline \multicolumn{2}{|c|}{ Demographic features and other information } & Average & Standard deviation & Sig. \\
\hline \multirow{2}{*}{ Voluntarily choosing the tourism department } & Yes & 3.4609 & 0.79169 & \multirow{2}{*}{.000} \\
\cline { 2 - 4 } & No & 2.7244 & 0.96375 & 0.85967 \\
\hline \multirow{2}{*}{ Any relatives working in tourism } & Yes & 3.3096 & 050 \\
\cline { 2 - 4 } & No & 3.1235 & 0.97583 \\
\hline
\end{tabular}

Source: authors' elaboration.

According to Table 4, while a significant difference was found between voluntarily choosing and level of hopelessness of the students, there was no significant difference between the other demographic variables. The $t$-test findings reveal that female students are more hopeful than male students, while those who choose voluntarily are more hopeful than those who did not.

Because of the analysis of variance carried out within the scope of the research, it was found that the desire to have a career in tourism varies significantly according to the reason for choosing the department. As given in Table 5, while students with the highest desire to pursue a career in tourism are in "gastronomy and culinary arts", students with the lowest willingness are in "food and beverage management". On the other hand, those who chose the department because of a love of the profession are more willing to have a career in tourism than those who chose for other reasons. Those who had to 
choose this department without any choice are the most reluctant to pursu e a career in tourism.

It was also revealed as a result of Variance Analysis that there was a significant difference in the level of hopelessness of the students according to the reason for choosing the department. As given in Table 6, students studying in the "gastronomy and culinary arts" department are more hopeful than in others, while students who study "accommodation management" have a lower level of hope than the others. On the other hand, students who chose a department without any other option have high levels of hopelessness, while students who chose a department with a love of the profession have lower levels. In the context of level of hopelessness, no significant difference was found with other variables.

Table 4. T-test findings on differences in level of hopelessness relative to demographics and other information

\begin{tabular}{|l|c|c|c|c|}
\hline \multicolumn{2}{|c|}{ Demographic features and other information } & Average & Standard deviation & Sig. \\
\hline \multirow{2}{*}{ Gender } & Female & 6.9010 & 4.43281 & .011 \\
\cline { 2 - 5 } & Male & 7.9894 & 3.86398 & .14754 \\
\multirow{2}{*}{ Voluntarily choosing the tourism department } & Yes & 6.8199 & 4.147 & .000 \\
\cline { 2 - 5 } & No & 8.7983 & 3.97573 & \\
\hline
\end{tabular}

Source: authors' elaboration.

Table 5. Variance analysis findings on differences in the desire to pursue a career in tourism according to demographic and other information

\begin{tabular}{|c|c|c|c|c|}
\hline \multicolumn{2}{|c|}{ Demographic and other information } & Average & $\begin{array}{l}\text { Standard } \\
\text { deviation }\end{array}$ & Sig. \\
\hline \multirow{5}{*}{ Department } & Department of Hospitality Management & 3.1885 & 1.00613 & \multirow{5}{*}{.008} \\
\hline & Food and Beverage Management & 2.9774 & 0.88540 & \\
\hline & Tourism Guidance & 3.3400 & 0.90785 & \\
\hline & Recreation Management & 3.4037 & 0.63759 & \\
\hline & Gastronomy and Culinary Arts & 3.5355 & 0.73962 & \\
\hline \multirow{5}{*}{ Reason for choosing the department } & Based on results & 2.9634 & 0.93266 & \multirow{5}{*}{.000} \\
\hline & Loving this job & 3.7086 & 0.72646 & \\
\hline & This course is valid for the tourism industry & 3.3873 & 0.67441 & \\
\hline & I had no other choice & 2.6605 & 0.85852 & \\
\hline & Relatives' advice & 3.0724 & 1.04639 & \\
\hline
\end{tabular}

Source: authors' elaboration.

Table 6. Variance Analysis regarding differences in levels of hopelessness according to demographic features and other information

\begin{tabular}{|c|c|c|c|c|}
\hline \multicolumn{2}{|c|}{ Demographic and other information } & Average & $\begin{array}{l}\text { Standard } \\
\text { deviation }\end{array}$ & Sig. \\
\hline \multirow{5}{*}{ Department } & Department of Hospitality Management & 8.9135 & 3.18403 & \multirow{5}{*}{.000} \\
\hline & Food and Beverage Management & 8.2688 & 3.87618 & \\
\hline & Tourism Guidance & 6.5760 & 4.51746 & \\
\hline & Recreation Management & 5.8519 & 4.65505 & \\
\hline & Gastronomy and Culinary Arts & 4.8710 & 4.00618 & \\
\hline \multirow{5}{*}{ Reason for choosing the department } & Based on results & 7.8944 & 4.37223 & \multirow{5}{*}{.004} \\
\hline & Loving this job & 6.4310 & 3.97651 & \\
\hline & This course is valid for the tourism industry & 6.9818 & 4.04828 & \\
\hline & I had no other choice & 9.0000 & 3.22155 & \\
\hline & Relatives' advice & 8.0690 & 4.67464 & \\
\hline
\end{tabular}

Source: authors' elaboration. 
Table 7. Correlation analysis findings regarding the relationship between level of hopelessness and a career in tourism

\begin{tabular}{|c|c|c|}
\hline Variables & Pearson correlation & Sig. \\
\hline Level of despair & -0.214 & .000 \\
\hline
\end{tabular}

Source: authors' elaboration.

As given in Table 7, a significant and negative relationship was found between the level of hopelessness in students and their desire to pursue a career in tourism. In other words, as the level of hopelessness of students increases, there is a decrease in pursuit of a career in tourism.

\section{DISCUSSION, CONCLUSION AND SUGGESTIONS}

In this work, which was conducted to reveal the relationship between the level of hopelessness in students who received tourism education at the undergraduate level at Sinop University and their desire to pursue a career in tourism. It was concluded that the increase in the level of hopelessness negatively affected the desire to pursue a career in tourism. Contrary to this result, Yildirım and Toker (2017) could not detect any relationship between level of hopelessness and career choice. However, Dieringer, Lenz, Hayden and Peterson (2017) revealed that level of hopelessness influenced career thinking. In this context, it can be said that the findings here do not match Dieringer, Lenz, Hayden and Peterson (2017), but do not correspond with Yildirım and Toker (2017) either.

In the research, it was also revealed that the students had a level of hopelessness of 7.4395. Considering that a maximum of 20 can be obtained, this level is below average. Similarly, it has been suggested that associate tourism program students have a despair level of 7.2033 in the Black Sea Region (Türkoğlu, Misican, 2018). Tanriverdi, Yilmaz, Pala and Ercan (2019) found the average of a desire to pursue a career in tourism as 3.590 and interpreted this as a high desire to pursue a career in tourism since five was the maximum. The result obtained from this research is 3.2303 , therefore it can also be said that students' desire to have a career in tourism is high.

The research revealed that both the level of hopelessness and the desire to pursue a career in tourism differ according to the reason for choosing the tourism department. Students who have no choice but to come to this department have less interest in pursuing a career in tourism than students who selected other educational courses. In addition, it was revealed that the level of despair of these students was higher than for others. As a result of the research, it was determined that students with the highest desire to pursue a career in tourism and the lowest level of hopelessness were students of "Gastronomy and Culinary Arts" and "Recreation Management". Henceforth, considering the reasons for this situation in Turkey, then a new chapter should open with preferences for active learning as compared to other options where practical exposure is less.

Considering these results, specific suggestions were developed. As this work is limited to Sinop University's School of Tourism and Hotel Management, it is recommended that this research is carried out within other institutions to expand its range. Career days where universities can network with the sector should be organized more frequently in order to maintain the students' desire to pursue a career in tourism and to decrease their levels of despair. During tourism weeks or similar co-curricular events, it can be ensured that tourism students throughout the province organize and manage activities related to their fields and be rewarded for this process. It is thought that introducing similar activities and giving students responsibility will increase their desire to pursue a career in tourism and decrease their level of hopelessness. Considering that recreation increases the quality of life and reduces hoplelessness, it is thought that tourism-based social, sporting, cultural and individual activities offered to students will positively affect their hope and desire to pursue a career in tourism. Low levels of despair in Gastronomy and Culinary Arts and Recreation Management departments and a high desire to pursue a career in tourism are seen as a result of better opportunities for the future offered by these existing departments in comparison to new departments. Therefore, the state administration should create employment for students graduating from these departments which will simultaneously contribute to student career plans.

\section{REFERENCES}

Acar, Y. (2019). Türkiye'de Yaşam Memnuniyetinin Belirleyicileri: İller Üzerine Bir Yatay Kesit Analizi. Maliye Araştırmaları Dergisi, 5 (2), 145-157.

Akagündüz, M. (2017). Turizm Öğrencilerinin Sektöre Yönelik İmaj Algılarının Kariyer Yapma İstekleri Üzerine Etkisi: Ege Bölgesinde Bir Uygulama. Master Thesis. Afyonkarahisar: Afyon Kocatepe Üniversitesi Sosyal Bilimler Enstitüsü.

Amil, O. (2015). Çalışanların Algılanan Kariyer Engelleri ile Algılanan Performansları Arasındaki İlişkinin Çeşitli 
Değişkenler Açısından İncelenmesi. Türkiye Sosyal Politika ve Çalışma Hayatı Araştırmaları Dergisi, 5 (9), 7-26.

Aydın, E.B. (2007). Örgütlerde Kariyer Yönetimi, Kariyer Planlaması, Kariyer Geliştirmesi ve Bir Kariyer Geliştirme Programı Olarak Koçluk Uygulamaları. Master thesis. Denizli: Pamukkale Üniversitesi Sosyal Bilimler Enstitüsü.

Baltacı, M., Çakıcı, A.C., Dönmez, B. (2019). The mediation role of academic procrastination on the effect of the university students' long-term orientation to career intention in the tourism industry. Journal of Tourism Theory and Research, 5 (3), 340-354. DOI: https://doi.org/10.24288/jttr.550746

Bamford, K.L. (2012). Undergraduate student perceptions of a career in the tourism and hospitality industry in New Zealand. Master thesis. University of Otago.

Beck, A.T. (1987). Cognitive models of depression. Journal of Cognitive Psychotherapy, 1 (1), 5-37.

Beck, A.T., Weissman, A., Lester, D., Trexler, L. (1974). The measurement of pessimism: The lack of hope scale. Journal of Consulting and Clinical Psychology, 42 (6), 861-865. DOI: https:// doi.org/10.1037/h0037562

Çelik, A., Akgemci, T., Korkmaz, V. (2017). The effect of lack of hope levels on sectorel attitudes of the tourism students: sample of Selcuk University Beysehir Ali Akkanat Faculty of Tourism and Vocational School. Global Business Research Congress (PAP), 24-25 May 2017, Turkey, Istanbul.

Cooper, C., Shepherd, R. (1997). The relationship between tourism education and the tourism industry: Implications for tourism education. Tourism Recreation Research, 22 (1), 34-47. DOI: https://doi.org/10.1080/02508281.1997.11014784

Dieringer, D.D., Lenz, J.G., Hayden, S.C.W., Peterson, G.W. (2017). The relation of negative career throughts to depression and lack of hope. The Career Development Quarterly, 65 (2), 159-172. DOI: https://doi.org/10.1002/cdq.12089

Duman, T., Tepeci, M., Unur, K. (2006). Mersin'de Yükseköğretim ve Orta Öğretim Düzeyinde Turizm Eğitimi Almakta Olan Öğrencilerin Sektörün Çalışma Koşullarını Algılamaları ve Sektörde Çalışma İsteklerinin Karşılaştırılmalı Analizi. Anatolia: Turizm Araştırmaları Dergisi, 17 (1), 51-69.

Eddleston, K.A., Powell, G.N. (2008). The role of gender identity in explaining sex differences in business owners' career satisfier preferences. Journal of Business Venturing, 23 (2), 244-256. DOI: https://doi.org/10.1016/j.jbusvent.2006.11.002

Fouad, N.A., Guillen, A., Harris-Hodge, E., Henry, C., Novakovic, A., Terry, S., Kantamneni, N. (2006). Need, awareness and use of career services for college students. Journal of Career Assessment, 14 (4), 407-420. DOI: https://doi. org/10.1177/1069072706288928

Gault, J., Redington, J., Schlager, T. (2000). Undergraduate business internships and career success: Are thye related? Journal of Marketing Education, 22 (1), 45-53. DOI: https://doi. org/10.1177/0273475300221006

Heskett, J.L., Jones, T.O., Loveman, G.W., Sasser Jr., W.E., Schlesinger, L.A. (1994). Putting the service-profit chain to work. Harvard Business Review, 72 (March-April), 77-84.

Ilgaz Yıldırım, B.I., Toker, B. (2017). Lisans Düzeyinde Turizm Eğitimi Alan Öğrencilerin Yılmazlık, Umutsuzluk Durumları ve Sektörel Tutumlarının Kariyer Seçimleri Üzerine Etkileri. Journal of Travel and Hospitality Management, 14 (1), 76-89. DOI: https://doi.org/10.24010/soid.303665

Jarlström, M. (2000). Personality preferences and career expectations of finnish business students. Career Development International, 5 (3), 144-154. DOI: https://doi. org/10.1108/13620430010371919

Jenkins, A.K. (2001). Making a career of it? Hospitality students' future perspectives: An Anglo-Dutch study. International
Journal of Contemporary Hospitality Management, 13 (1), 13-20. DOI: https://doi.org/10.1108/09596110110365599

Koko, J., Guerrier, Y. (1994). Overeducation, underemployment and job satisfaction: A study of finnish hotel receptionists. International Journal of Hospitality Management, 13 (4), 375-386. DOI: https://doi.org/10.1016/0278-4319(94)90073-6

Kusluvan, S., Kusluvan, Z. (2000). Perceptions and attitudes of undergraduate tourism students towards working in the tourism industry in Turkey. Tourism Management, 21 (3), 251-269. DOI: https://doi.org/10.1016/S0261-5177(99)00057-6

Manhas, P., Dogra, J. (2011). Hospitality and tourism management graduates expectations: Future implications for the educators. Journal of Tourism, XII (1), 103-112.

O'Leary, S., Deegan, J. (2005). Career progression of Irish tourism and hospitality management graduates. International of Contemporary Hospitality Management, 17 (5), 421-432. DOI: https://doi.org/10.1108/09596110510604841

Orahood, T., Kruze, L., Pearson, D.E. (2004) The impact of study abroad on business students' career goals. Frontiers: The Interdisciplinary Journal of Study Abroad, 10 (1), 117-130. DOI: https://doi.org/10.36366/frontiers.v10i1.137

Pavesic, D.V., Brymer, R.A. (1990). Job satisfaction: What's happening to the young managers. The Cornell Hotel and Restaurant Administration Quarterly, 30 (4), 90-96. DOI: https:// doi.org/10.1177/001088049003000420

Pektaş, Ç. (2019). Gaziantep'te Ön Lisans Düzeyinde Turizm Eğitimi Alan Öğrencilerin Kariyer Planlamaları ve Turizm Sektörüne İlişkin Algılarının Değerlendirilmesi. Master thesis. Gaziantep: Gaziantep Üniversitesi Sosyal Bilimler Enstitüsü.

Purcell, K., Quinn, J. (1996). Exploring the education-employment equation in hospitality management: A comparison of graduates and HNDs. International Journal of Hospitality Management, 15 (1), 51-68. DOI: https://doi.org/10.1016/0278-4319(96)00002-3

Raymond, A.N. (2009). Insan Kaynaklarının Ĕ̆itimi ve Geliştirilmesi. 4. Baskı (Çeviren, Çetin, C.), İstanbul: Beta Basım Yayım Dağıtım.

Roney, S.A., Öztin, P. (2007). Career perceptions of undergraduate tourism students: A case study in Turkey. Journal of Hospitality, Leisure, Sport \& Tourism Education, 6 (1), 4-17. DOI: https://doi.org/10.3794/johlste.61.118

Rosentbluth, H. (1991). Tales from a nonconformist company. Harvard Business Review, 69 (July-August), 26-36.

Rottinghaus, P.J., Jenkins, N., Jantzer, A.M. (2009). Relation of depression and affectivity to career decision status and selfefficacy in college students. Journal of Career Assessment, 17 (3), 271-285. DOI: https://doi.org/10.1177/1069072708330463

School of Tourism and Hotel Management (2020). Retrieved from: http://www.turizm.sinop.edu.tr (29.06.2020).

Selvi, M.S., Demir, C. (2007). Relationship among branding, career development and tourism education: An implication from Turkey. Ege Akademik Bakış Dergisi, 7 (2), 389-408.

Simmons, S.A., Wiklund, J., Levie, J. (2014). Stigma and business failure: Implications for entrepreneurs' career choices. Small Business Economics, 42 (3), 485-505. DOI: https://doi. org/10.1007/s11187-013-9519-3

Solmaz, S.A., Erdoğan, Ç., Türkay, O., Korkutata, A. (2012). Sosyotropi ve Otonomi Kişilik Özelliklerinin Turizmde Kariyer Yapma İsteği Üzerine Etkileri, Bartın Üniversitesi İIBF Dergisi, 3 (5), 47-70.

Tanrıverdi, H., Yılmaz, A., Pala, B., Ercan, F.Z. (2019). Kişilik Özellikleri, Duygusal Zekâ, Kariyer Uyum Yeteneği ve Turizmde Kariyer Yapma İsteği Arasındaki İlişkilerin İncelenmesi: İstanbul Üniversitesinde Turizm İşletmeciliği Eğitimi Alan Öğrenciler Üzerine Bir Araştırma. Uluslararası Turizm, İşletme, Ekonomi Dergisi, 3 (1), 41-56. 
TUIK (2019). Retrieved from: http://www.tuik.gov.tr/ PreIstatistikTablo.do?istab_id=2421 (28.06.2020).

TUIK (2020). Retrieved from: http://www.tuik.gov.tr/ PreHaberBultenleri.do?id=33919 (28.06.2020).

Türk Dil Kurumu Sözlükleri (2020). Retrieved from: https://www. sozluk.gov.tr (15.06.2020).

Türkoğlu, N., Misican, D.Ö. (2018). Turizm Öğrencilerinin Algilarındaki Kariyer Engellerinin Kümelenmesi ve Umutsuzluk Düzeyi Skorları. VI International Multidisciplinary Congress of Eurasia (IMCOFE), 4-6 September 2018, Rome, Italy.

Walmsley, A., Thomas, R., Jameson, S. (2012). Internships in SMEs and Career Intentions. Journal of Education and Work, 25 (2), 185-204. DOI: https://doi.org/10.1080/13639080.2011.573774

Watson, C., Drew, V. (2015). Teachers' desire for career-long learning: Becoming 'accomplished' and masterly. British
Educational Research Journal, 41 (3), 448-461. DOI: https://doi. org/10.1002/berj.3149

Yeşilyaprak, B. (2012). Mesleki Rehberlik ve Kariyer Danışmanlığı: Kuramdan Uygulamaya (2. Baskı). Ankara: Pegem Akademi. DOI: https://doi.org/10.14527/9786053641742.01

Zellweger, T., Sieger, P., Halter, F. (2011). Should I stay or should I go? Career choice intentions of students with family business background. Journal of Business Venturing, 26 (5), 521-536. DOI: https://doi.org/10.1016/j.jbusvent.2010.04.001

Article received:

20 August 2020

Accepted:

17 December 2020 